\title{
A CINE-ANGIOGRAPHIC STUDY OF AORTIC VALVE DYNAMICS*
}

\author{
BY \\ EDWARD B. RAFTERY \\ From the Cardiac Department, St. Thomas's Hospital, London
}

Received June 22, 1964

Cine-angiographic techniques for the visualization of intracardiac structures have made it possible to study the movements of the heart valves in detail and correlate them with the hæmodynamic and phonocardiographic events of the cardiac cycle in the intact human subject. In this way classical concepts can be tested and the mechanism of certain events determined. This report concerns the movements of the aortic valve in normal subjects and a group of subjects with a variety of aortic valve abnormalities.

\section{SubJeCtS AND METHODS}

Studies were carried out on 60 patients with aortic valvular disease by retrograde arterial catheterization, combined with transseptal catheterization of the left ventricle in 17. Pressure recordings were made with simultaneous conventional and intracardiac phonocardiograms so that hæmodynamic and phonocardiographic events could be closely related. Cine-angiograms were made in all patients to show the movements of the valve, and these were correlated with the hæmodynamic and phonocardiographic recordings. A group of 15 patients who were undergoing retrograde arterial catheterization for selective coronary arteriography were studied in a similar fashion and provided the normal controls for the diseased valves.

Catheterization was performed by the percutaneous technique described by Seldinger (1953). With the aid of an image intensifier an Odman-Leydin catheter was passed from the femoral artery to the root of the aorta. With the tip of the catheter just above the aortic valve, a pressure recording was made with a simultaneous phonocardiogram taken from the aortic area or the lower left sternal border. The catheter was then passed through the valve to the left ventricle and a recording was made of a pull-back across the valve. In 17 patients a second catheter was passed from the femoral vein to the right atrium and by the transseptal route to the left atrium and ventricle. Simultaneous recordings were then made of the pressures in the aortic root and the left ventricle, and of aortic phonocardiograms. The pressures were measured by means of strain gauges $\dagger$ matched for amplitude and rate of response.

In several cases, intracardiac phonocardiograms were recorded from the aortic root and from the left ventricle. This was done by making use of a manometerł and amplifier as a resonator for those frequencies within the audible range, which were conducted along the column of saline in the catheter. Animal experiments showed that these recordings differed from recordings made with external microphones, some frequencies being considerably attenuated, but were delayed over external recordings by a negligible amount (2 msec.).

Cine-angiograms were performed by injecting hypaque under pressure into the root of the aorta with the patient in the left anterior oblique position. A $35-\mathrm{mm}$. camera running at a constant speed of 60 frames

* Part of this work was done in the Wellcome Research Laboratory of the Johns Hopkins Hospital, Baltimore, Md., U.S.A. in 1961-62 during the author's tenure as a Fellow in Medicine at the Johns Hopkins University School of Medicine, and a Wellcome Foundation Travelling Fellowship.

+ Statham Co.

$\ddagger$ Dallons-Telco Ltd. 


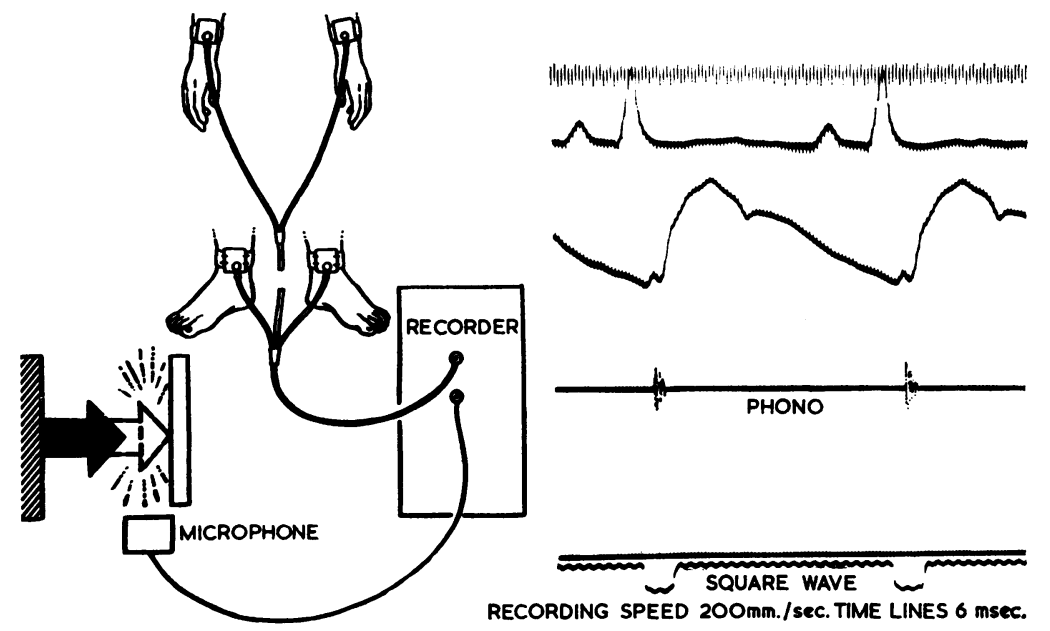

FIG. 1.-The method of determining the delay between the inscription of the square wave from the $R$ wave of the electrocardiogram and the movement of the arrow into the field of the cine-angiogram. The pressure tracing shown is from the aortic root. The delay is equal to the interval between the square wave and the sound. The interval between QII and the square wave varies in each case and can easily be measured.

per sec. was used to record the angiogram, and the position allowed a clear view of all three cusps and their movements. After developing, the angiogram was viewed with a $35-\mathrm{mm}$. projector* which was operated by hand and allowed frame-by-frame analysis of the events.

Pressures and phonocardiograms were recorded on a photographic recorder $\dagger$ at paper speeds of $75 \mathrm{~mm}$. per sec. with $40 \mathrm{msec}$. time lines, or $200 \mathrm{~mm}$. per sec. with $6 \mathrm{msec}$. time lines. Lead II of the electrocardiogram was used as a reference trace in all recordings. All the patients reported were in sinus rhythm, with a QRS interval less than 120 msec.

Co-ordination of Valve Movement with Hamodynamic and Phonocardiographic Events. In order to relate the cine-angiographic events with the pressures and sounds, the $\mathbf{R}$ wave of the electrocardiogram was converted to a square wave which was inscribed on the same recording. The interval from the $Q$ wave (henceforth referred to as QII) to this square wave varied, depending upon the height and the slope of the R wave, but could be measured in each individual patient. This square wave also activated a relay attached to the shutters of the image intensifier so that a lead arrow moved out into the camera field. The relay and the inertia of the arrow introduced a delay between the inscription of the square wave and movement of the arrow. This delay was determined by placing a metal object a very short distance from the tip of the arrow and recording the sound made when the arrow moved (Fig. 1). The interval between the square wave and the sound was $25 \mathrm{msec}$. Thus the time between QII and the movement of the arrow was equal to the Q II-square wave time plus $25 \mathrm{msec}$.

The measurement of hæmodynamic and phonocardiographic events from the $Q$ wave of the cardiogram could be made with considerable accuracy, particularly at the high recording speeds used, but greater inaccuracy was inherent in the interpretation of the cine-angiograms. The relation between the movement of the arrow and Q II was well defined, but since each frame of the cine-angiograms occupied a time interval of $16.67 \mathrm{msec}$. (film speed 60 frames per sec.) it was impossible to say at which point in this interval the arrow actually started to move.

In order to relate a cine-angiographic event to the appearance of the arrow, the number of frames between the frame in which the arrow first started to move and the frame in which the event first appeared was counted and multiplied by 16.67. Clearly, as with the arrow, it was impossible to be sure at which point in the exposure of the last frame the event actually took place. This was expressed by assuming that the event took place at the mid-point of exposure of the frame. Hence, the maximal possible timing error was $\pm 8.33 \mathrm{msec}$. and if the event occurred at some other point of the exposure, the error must have been less than

* Tage-Arno, Model RC-35.

† Electronics for Medicine, Model DR-8. 


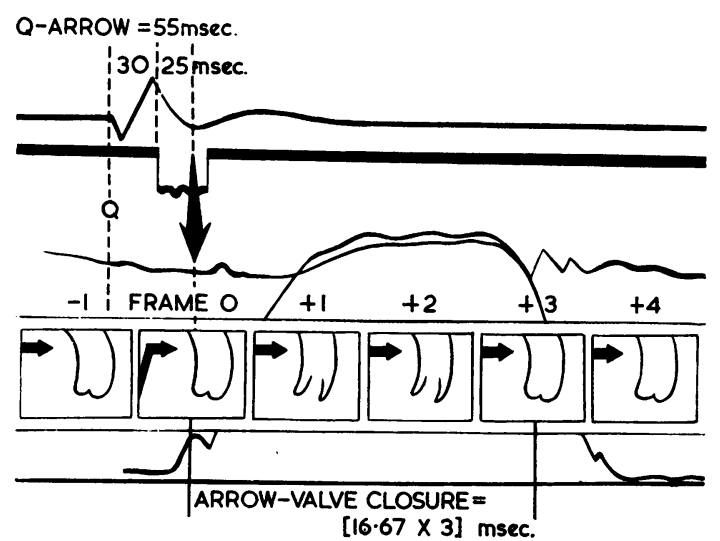

Fig. 2.-It is assumed that the arrow moves and the event being timed takes place at the mid-point of their respective frames. Hence the maximal possible error for each is $\pm 8.33 \mathrm{msec}$. and the total possible error is $16.67 \mathrm{msec}$. If the arrow moved or the event took place at some other point in the frame exposure the error must be less than this. this. But this argument applied to two framesthe one in which the arrow moved and the one in which the event appeared. Hence, the maximal possible error for the whole time interval Q II-cine event was $\pm 16.67 \mathrm{msec}$. (Fig. 2). This figure in fact represents the 100 per cent confidence limits for the time interval. Should a phonocardiographic or hæmodynamic event occur within $\pm 16.67 \mathrm{msec}$. of the Q II-cine event interval, it was possible that they were causally related. Should the interval be greater than this, it was quite impossible that the two events could be causally related.

Measurements of Time Intervals. The intervals from the $Q$ wave of the electrocardiogram to the ejection click and the aortic component of the second heart sound were measured directly from the photographic recording since the techniques used introduced no delay (Braunwald et al., 1955; Leatham and Vogelpoel, 1954). However, the hæmodynamic recordings were subject to a delay in recording due to the length of the catheter used and the time taken for a pressure wave to be conducted along it. A simple experiment was performed to determine this delay. A catheter was filled with saline and connected with a Statham gauge in the usual fashion. A saline-filled syringe was attached to the other end of the catheter and a pressure wave induced in the system by tapping the end of the plunger with a metallic object (Fig. 3). The sound of the tap was recorded by means of a microphone, and the interval between this sound and the record of the pressure wave represented the delay due to transmission in the catheter. In several experiments the delay averaged $10 \mathrm{msec}$. with a range of $9 \mathrm{msec}$. to $12 \mathrm{msec}$. The average figure was subtracted from the measured time intervals to give the true timing of each pressure event.

These measurements of time intervals allowed some observations to be made on the sub-divisions of the cardiac cycle, and the way in which they are altered by disease of the aortic valve. Accurate measurements were made of the electrical-mechanical interval, the isometric contraction time, and the ejection time.

The electrical-mechanical interval was measured as the time interval between the onset of electrical and mechanical activity in the ventricle. Following the convention used by previous workers, Q II was taken as the

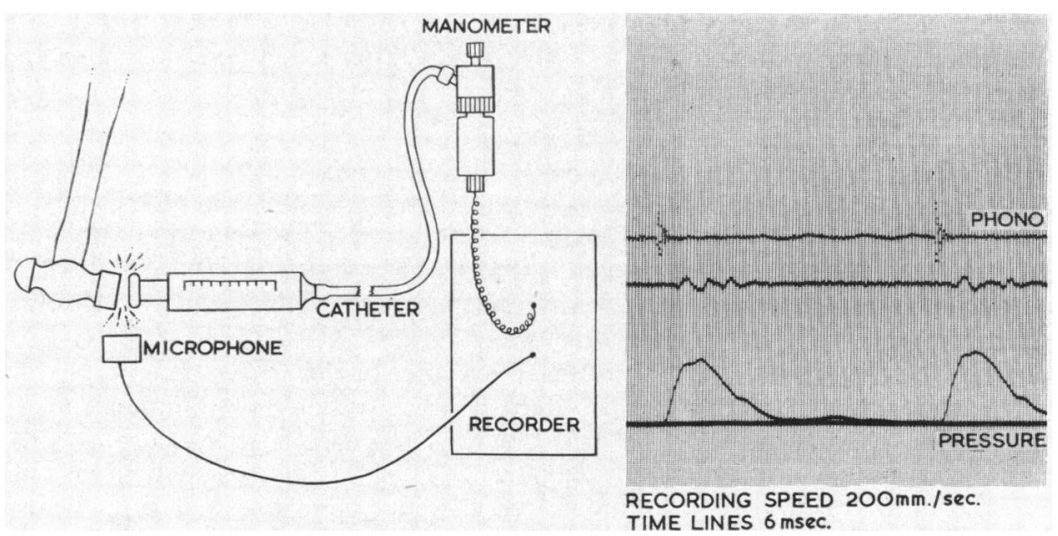

FIG. 3.-The method of estimating the delay in timing introduced by the catheter. The interval between the sound and the pressure rise in the syringe averaged $10 \mathrm{msec}$., and this figure was subtracted from all catheter timings. 
TABLE I

Summary of Cine-angiographic Appearance of Aortic Valves Studied

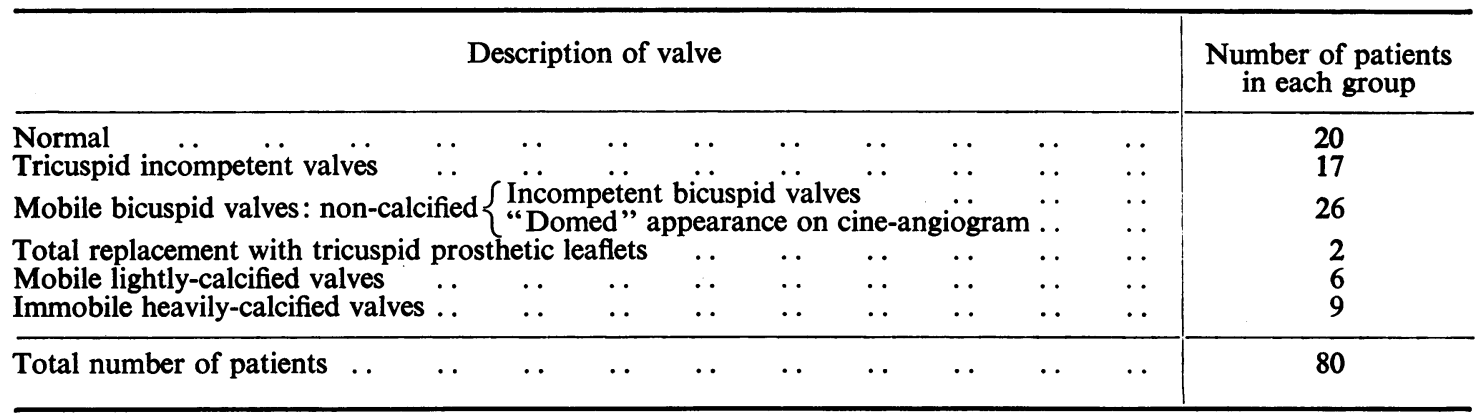

beginning of ventricular electrical activity. The onset of mechanical activity was taken as the first rapid rise of pressure in the left ventricle. This corresponded closely with the mitral component of the first heart sound (Braunwald et al., 1955). Isometric contraction time was measured as the interval between this rapid rise in pressure and the first pressure rise in the aortic root. These points are usually taken to represent mitral valve closure and aortic valve opening respectively (Wiggers, 1949). Ejection time was measured as the interval between the onset of pressure rise in the aortic root and the dicrotic notch. This includes a very small interval between the end of ejection and closure of the valve (protodiastole), but this is very constant and has been included by all previous observers in their measurements of ejection time.

Direct comparison of these intervals was not possible because there were such wide individual differences in factors such as heart rate, aortic diastolic pressure, and left ventricular end-diastolic pressure, which were bound to influence all or some of them. This difficulty was overcome by grouping the patients according to their anatomical variety of aortic valve and comparing the abnormal groups with the control group using a method of multiple analyses of co-variance which allowed for as many of these factors as could be measured.

\section{RESULTS}

Co-ordination of Valve Movements with Hamodynamic and Phonocardiographic Events. Pressures and sounds were related to valve movement in 59 patients. Table I groups the patients according to the anatomical variety of their aortic valves: 12 of the patients with bicuspid valves are grouped separately in the later tables because they showed a very characteristic appearance on the cine-angiogram.

Tables II and III show that there was close agreement between valve opening and pressure rise in the aortic root in the group with normal valves and in the group with incompetent tricuspid aortic valves. Similarly, there was close agreement between the aortic component of the second heart sound, the dicrotic notch, and valve closure in both groups. These points are illustrated in Fig. 4A and 4B.

The patients with bicuspid non-calcified aortic valves all had ejection clicks which could be heard clinically and recorded on the phonocardiograph. Table IV shows the timing relationships of 6 of these patients with pure aortic incompetence. It can be seen that the ejection click was considerably later than the pressure rise in the aortic root, and that valve opening corresponded more closely with the click than with the pressure rise. The average interval between the aortic pressure rise and valve opening was $48 \mathrm{msec}$, and this is well outside the 100 per cent confidence limits of $\pm 16.67 \mathrm{msec}$; ; it also corresponds to three frames of the cine-angiogram. On the other hand, there was again close agreement between the second heart sound, the dicrotic notch, and valve closure. Twelve patients with bicuspid non-calcified valves presented a very characteristic appearance on cine-angiography. During systole the aortic valve suddenly snapped upwards into the aortic root to give the appearance of a dome from the apex of which a jet emerged (Fig. 5B): at the end of systole this "dome" collapsed as suddenly as it had appeared. All these patients had loud ejection clicks and loud second heart sounds. Most had mixed stenosis and incompetence, and in some the degree 
TABLE II

Group I: Normal Aortic Valves

Relationship of Hemodynamic and Phonocardiographic Events to Valve Movement (all time intervals in msec.)

\begin{tabular}{c|c|c|c|c|c|c}
\hline Patient & $\begin{array}{c}\text { Q aortic* } \\
\text { pressure } \\
\text { rise }\end{array}$ & $\begin{array}{c}\text { Q valve† } \\
\text { open }\end{array}$ & $\begin{array}{c}\text { Q dicrotic* } \\
\text { notch }\end{array}$ & $\begin{array}{c}\text { Q second } \\
\text { heart } \\
\text { sound }\end{array}$ & $\begin{array}{c}\text { Q valve† } \\
\text { closed }\end{array}$ & Diagnosis \\
\hline K.D. & 125 & 135 & 390 & - & 400 & Coronary artery disease \\
P.F. & 95 & 95 & 375 & - & 360 & Coronary artery disease \\
W.L. & 90 & 95 & 430 & - & 425 & Coronary artery disease \\
K.R. & 95 & 110 & 430 & 430 & 440 & Coronary artery disease \\
R.B. & 110 & 110 & 365 & - & 360 & Coronary artery disease \\
E.S. & 90 & 85 & 360 & 360 & 355 & Coronary artery disease \\
M.C. & 95 & 105 & 405 & - & 410 & Coronary artery disease \\
R.B. & 95 & 105 & 400 & 400 & 400 & Coronary artery disease \\
L.P. & 95 & 110 & 360 & 365 & 370 & Patent ductus arteriosus \\
J.B. & 135 & 145 & 415 & 415 & 410 & Patent ductus arteriosus \\
B.D. & 70 & 80 & 310 & 310 & 315 & Tetralogy of Fallot (complete \\
r.S. & 125 & 130 & 380 & 380 & 370 & Atrial and ventricular septal \\
R.S. & 95 & 100 & 305 & 305 & 295 & Mitral regurgitation \\
A.M. & 95 & 130 & 405 & 405 & 395 & Coronary A-V fistula \\
C.M. & 120 & 140 & 360 & 360 & 350 & Coronary A-V fistula \\
J.Y. & 135 & 111 & 379 & 373 & 377 & \\
\hline Mean values & 104 & 11 & &
\end{tabular}

* Pressure timings corrected for delay due to catheter transmission.

$\dagger$ All cine-angiographic timings subject to an error of $\pm 16 \cdot 67 \mathrm{msec}$.

of stenosis was very severe. Table $\mathrm{V}$ shows that the timing relationships for these patients were essentially similar to those shown in Table IV. Again the aortic root pressure rose considerably before the valve appeared to open. The appearance of the "dome" corresponded closely to the ejection click. The second heart sound, the dicrotic notch, and the collapse of the valve "dome" all corresponded closely (Fig. 5A and 5B).

\section{TABLE III}

Group II: INCOMPETENT TRICUSPID AORTIC VALVES

Relationship of Hemodynamic and Phonocardiographic Events to Valve Movement (all time intervals in msec.)

\begin{tabular}{|c|c|c|c|c|c|c|}
\hline Patient & $\begin{array}{l}\text { Q aortic* } \\
\text { pressure } \\
\text { rise }\end{array}$ & $\begin{array}{c}\mathbf{Q} \text { valve } \\
\text { open }\end{array}$ & $\underset{\text { notch }}{Q \text { dicrotic* }}$ & $\begin{array}{l}\text { Q second } \\
\text { heart } \\
\text { sound }\end{array}$ & $\begin{array}{l}\mathbf{Q} \text { valve† } \\
\text { closed }\end{array}$ & Aetiology \\
\hline $\begin{array}{l}\text { J.M. } \\
\text { V.J. } \\
\text { B.M. } \\
\text { J.H. } \\
\text { C.A. } \\
\text { T.H. } \\
\text { P.Y. } \\
\text { E.T. } \\
\text { J.G. } \\
\text { M.W. } \\
\text { B.N. }\end{array}$ & $\begin{array}{r}100 \\
105 \\
100 \\
100 \\
85 \\
75 \\
85 \\
70 \\
95 \\
105 \\
90\end{array}$ & $\begin{array}{r}100 \\
115 \\
105 \\
110 \\
90 \\
80 \\
95 \\
75 \\
90 \\
105 \\
100\end{array}$ & $\begin{array}{l}400 \\
320 \\
380 \\
445 \\
320 \\
325 \\
-190 \\
385 \\
360 \\
370\end{array}$ & $\begin{array}{l}400 \\
320 \\
380 \\
445 \\
320 \\
325 \\
340 \\
-385 \\
360 \\
370\end{array}$ & $\begin{array}{l}400 \\
330 \\
370 \\
445 \\
325 \\
325 \\
345 \\
300 \\
375 \\
355 \\
380\end{array}$ & $\begin{array}{l}\text { Rheumatic } \\
\text { Rheumatic } \\
\text { Rheumatic } \\
\text { Rheumatic } \\
\text { Syphilitic } \\
\text { Syphilitic } \\
\text { Syphilitic } \\
\text { Syphilitic } \\
\text { Prolapse of one cusp } \\
\text { Tetralogy of Fallot } \\
\text { Marfan's syndrome }\end{array}$ \\
\hline Mean values & 92 & 97 & 359 & 364 & 352 & \\
\hline
\end{tabular}

* Pressure timings corrected for delay due to catheter transmission.

+ All cine-angiogram timings subject to an error of $\pm 16.67 \mathrm{msec}$. 
Table VI shows similar findings in two patients whose aortic valves had been completely replaced by artificial leaflets. Both developed ejection clicks after operation, but the clicks were much later in the cardiac cycle than is usual in patients with natural valves. Nevertheless, they were again closely related to valve opening and delayed over the aortic root pressure.

Table VII shows the timing data of a small group of patients with mobile valves that were lightly calcified. This shows a similar delay between the rise of pressure in the aortic root and valve opening. In only one patient was an ejection click recorded, and this corresponded with valve opening. The relation between the aortic second sound, the dicrotic notch, and valve closure, was close as in the other groups.

The final group of patients all had heavily calcified immobile aortic valves. Table VIII shows the timing data from these patients. Valve movement was slight in all cases and was not easily observed on the cine-angiogram. However, as far

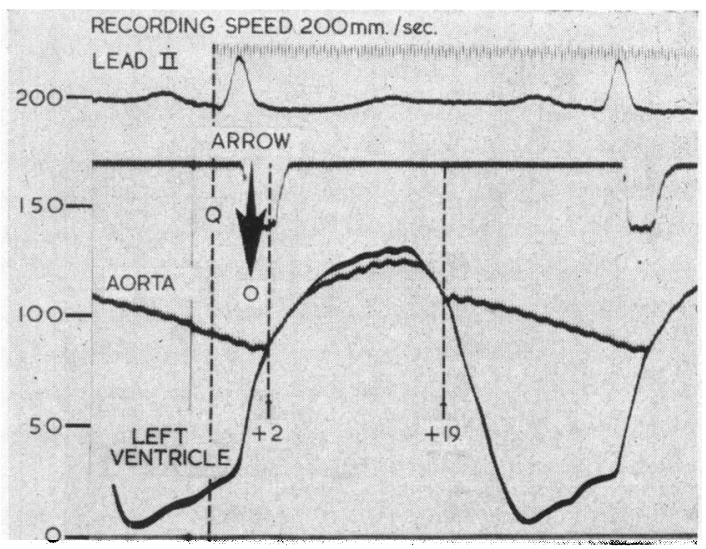

FIG. 4A.-Patient R.B. High-speed recording taken during a pull-back across the aortic valve. Left ventricular pressure traced and superimposed upon aortic pressure. The numbers refer to cine-angiogram frames numbered from the frame in which the arrow first moved (frame 0 ). The arrow begins to move $25 \mathrm{msec}$. after the square-wave is inscribed. Calibration in $\mathrm{mm}$. $\mathrm{Hg}$. as could be judged, valve opening again appeared to be delayed over the rise of aortic root pressure. No ejection clicks were recorded. At the other end of the cardiac cycle it was often difficult to identify accurately the aortic component of the second heart sound, but where this could be done it appeared to coincide with the dicrotic notch and with valve closure. In those cases in which simultaneous left ventricular and aortic root pressures were

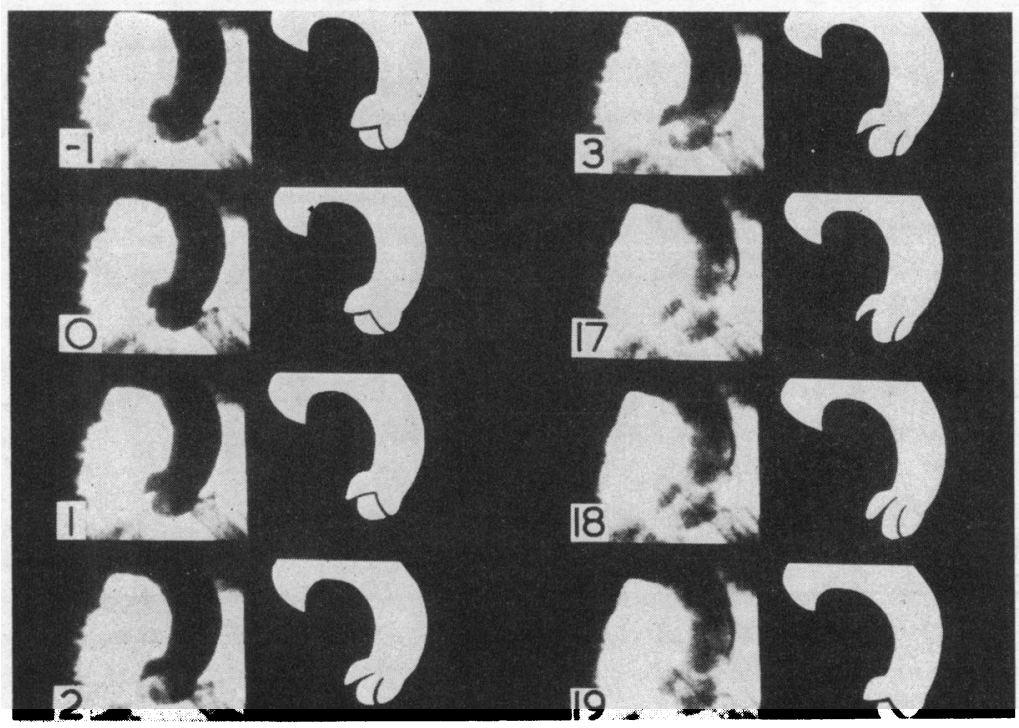

FIG. 4B.-Patient R.B. Individual frames taken from one cardiac cycle. Frames numbered from the frame in which the arrow first moved (frame 0 ). The middle frames of the cycle have been omitted to avoid repetition. Note that all three cusps are clearly defined and that the first appearance of blood in the aorta can be easily seen (frame 2). Similarly, valve closure is easily seen (frame 19). This figure should be compared with Fig. 4A. 
TABLE IV

Group III: INCOMPETENT Bicuspid AORTIC VALVES

Relationship of Hamodynamic and Phonocardiographic Events to Valve Movement (all time intervals in msec.)

\begin{tabular}{c|c|c|c|c|c|c}
\hline Patient & $\begin{array}{c}\text { Q aortic* } \\
\text { pressure } \\
\text { rise }\end{array}$ & $\begin{array}{c}\text { Q ejection } \\
\text { click }\end{array}$ & $\begin{array}{c}\text { Q valve† } \\
\text { open }\end{array}$ & $\begin{array}{c}\text { Q dicrotic* } \\
\text { notch }\end{array}$ & $\begin{array}{c}\text { Q second } \\
\text { heart } \\
\text { sound }\end{array}$ & $\begin{array}{c}\text { Q valve† } \\
\text { closed }\end{array}$ \\
\hline T.A. & 90 & 135 & 135 & 415 & 415 & 420 \\
D.M. & 85 & 130 & 135 & 445 & 445 & 445 \\
G.R. & 50 & 120 & 130 & 325 & 325 & 320 \\
J.L. & 75 & 120 & 125 & 470 & 470 & 470 \\
S.H. & 70 & 110 & 100 & 310 & 310 & 300 \\
S.C. & 80 & 110 & 115 & 350 & 350 & 360 \\
\hline Mean values & 75 & 121 & 123 & 386 & 386 & 386 \\
\hline
\end{tabular}

* Pressure timings corrected for delay due to catheter transmission.

$\dagger$ All cine-angiogram timings subject to an error $\pm 16.67 \mathrm{msec}$.

\section{TABLE V}

Group III: Bicuspid Aortic Valves with “Domed” Appearance in Systole

Relationship of Hemodynamic and Phonocardographic Events to Valve Movement (all time intervals in msec.)

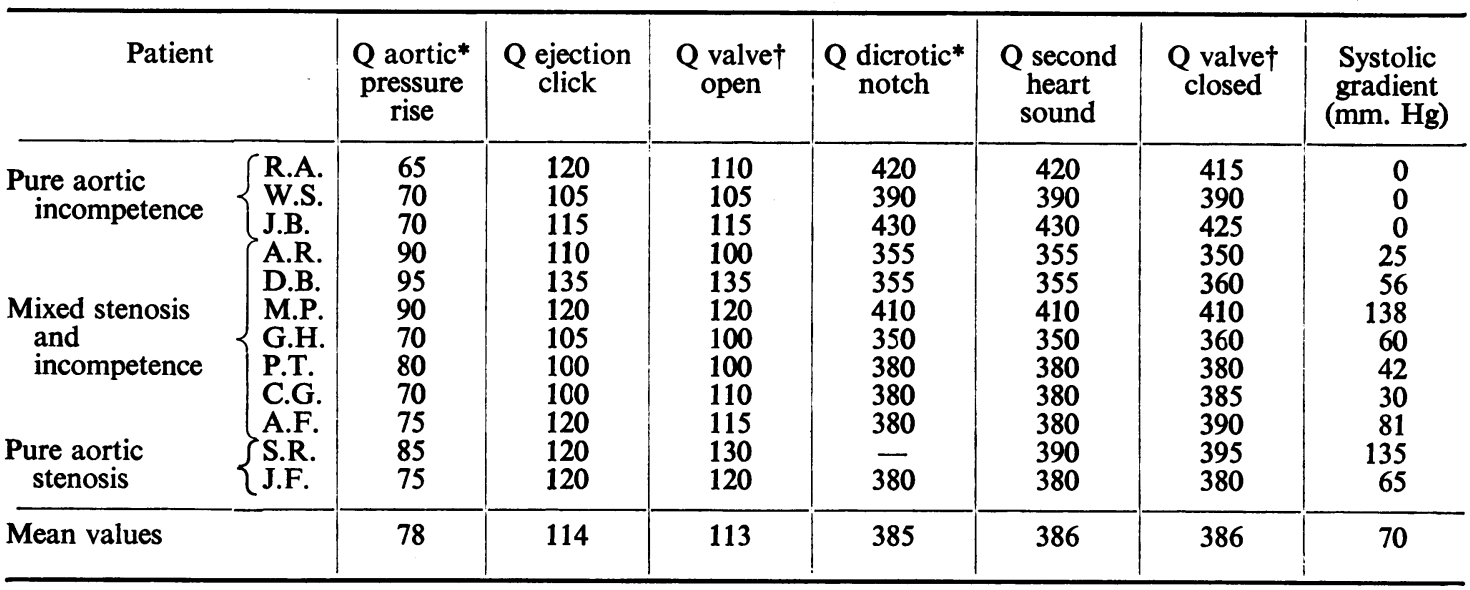

* Pressure timings corrected for delay due to catheter transmission.

$\dagger$ All cine-angiogram timings subject to an error of $\pm 16 \cdot 67 \mathrm{msecs}$.

TABLE VI

Tricuspid Prosthetic Aortic Valves

Relationship of Hemodynamic and Phonocardiographic Events to Valve Movement (all time intervals in msec.)

\begin{tabular}{c|c|c|c|c|c|c}
\hline Patient & $\begin{array}{c}\text { Q aortic* } \\
\text { pressure } \\
\text { rise }\end{array}$ & $\begin{array}{c}\text { Q ejection } \\
\text { click }\end{array}$ & $\begin{array}{c}\text { Q valve† } \\
\text { open }\end{array}$ & $\begin{array}{c}\text { Q dicrotic* } \\
\text { notch }\end{array}$ & $\begin{array}{c}\text { Q second } \\
\text { heart } \\
\text { sound }\end{array}$ & $\begin{array}{c}\text { Q valve† } \\
\text { closed }\end{array}$ \\
\hline \begin{tabular}{l|c|c|c|} 
R.C. \\
J.H.
\end{tabular} & 110 & 155 & 150 & 370 & 370 & 370 \\
\hline
\end{tabular}

* Pressure timings corrected for delay due to catheter transmission.

$\dagger$ All cine-angiogram timings subject to an error of $\pm 16.67 \mathrm{msec}$. 
obtained, it seemed that the dicrotic notch did not coincide with the point at which the left ventricular pressure fell below that in the aortic root, but was considerably later. Since timing these cases was very difficult and the dicrotic notch could not be identified with the second heart sound in all cases this observation might have been artefactual (Fig. 6).

In all the groups with valvular disease the aortic root pressure tracing was similar (Fig. 7). There was an initial sharp rise in pressure, and when simultaneous left ventricular and aortic root pressures were available, it could be seen that this pressure rise corresponded with the rise of left ventricular pressure above that in the aortic root. This initial rise was followed in most cases by a sudden steep fall in pressure. In those cases in which the pressure did not fall there was a distinct break in the recording. This point corresponded with valve opening in all cases and with the ejection click when it was present. The pressure then slowly rose in an irregular fashion to its maximum and terminated in the dicrotic notch. In the group

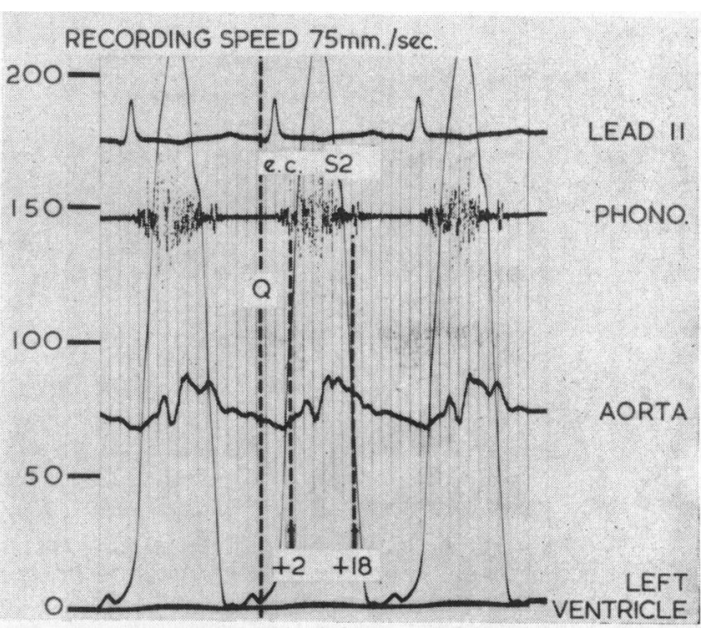

FIG. 5A.-Patient S.R. Simultaneous left ventricular and aortic root pressures with a phonocardiogram taken from the aortic area. The ejection sound (e.c.) occurs later than the point at which left ventricular pressure exceeds that in the aortic root. Note the intensity of the second heart sound (S2). The numbers refer to frames shown in Fig. 5B. Calibration in $\mathrm{mm}$. $\mathrm{Hg} ; 40 \mathrm{msec}$. time lines. of heavily calcified valves, the dicrotic notch was often absent or difficult to identify.

In several patients it was possible to record intracardiac phonocardiograms together with

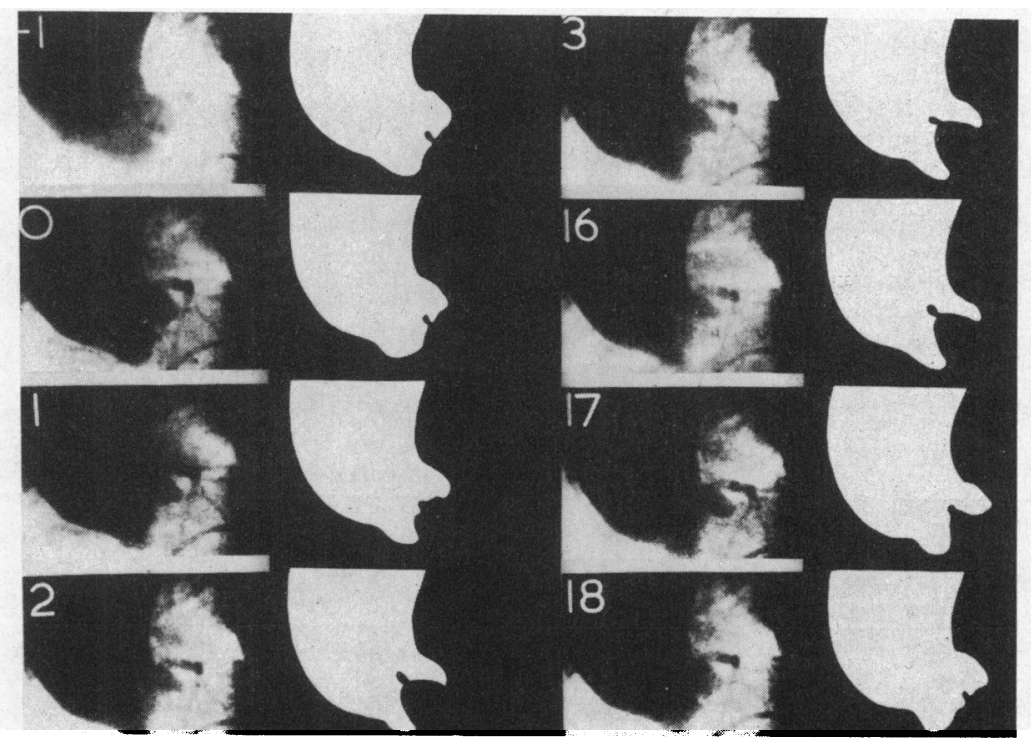

Fig. 5B.-Patient S.R. Frames taken from a single cardiac cycle. The valve has only two cusps (frame 1), and can be seen to move upwards before suddenly assuming a dome-like shape (frame 2). The middle frames of the cycle have been omitted to avoid repetition. In the later frames the "dome" collapses as suddenly as it appears. These events correspond with the ejection sound and the second heart sound respectively (Fig. 5A). 


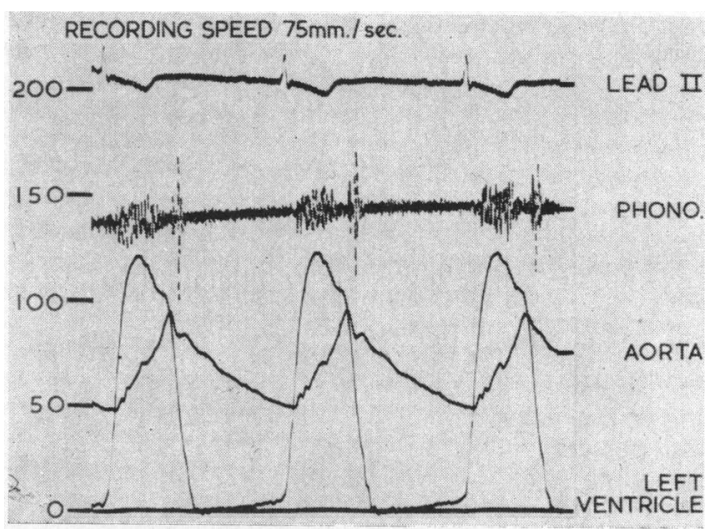

FIG. 6.-Patient S.V. Simultaneous left ventricular and aortic root pressure recordings. Note that both components of the second heart sound can be clearly seen. The dicrotic notch is inscribed later than the point at which the two pressures cross and coincides with the second heart sound. Note that the murmur does not begin with the first crossing of the two pressures but at the peak of the first rise in pressure.

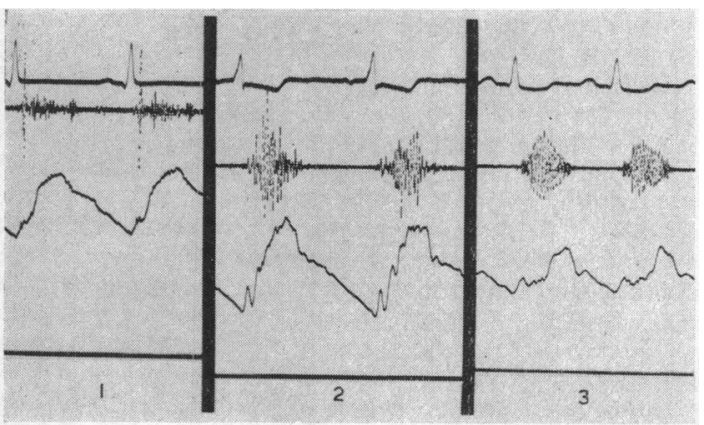

FIG. 7.-1=Patient W.S. (Group III), incompetent bicuspid valve. $2=$ Patient W.E. (Group IV), mobile calcified valve. 3=Patient R.B. (Group V), immobile calcified valve. Aortic root pressure tracings in each case. Note the similarity in that an initial pressure rise precedes the murmur in each case. An ejection sound is recorded at the peak of the first pressure rise in Patient W.S.

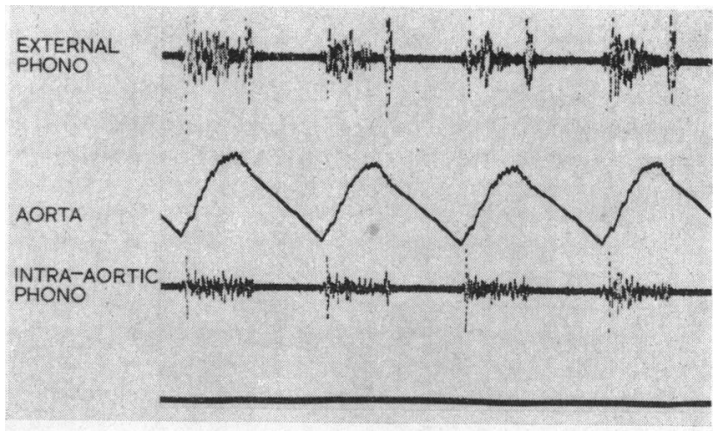

FIG. 8.-Patient W.S. Incompetent bicuspid aortic valve (Group III). Aortic root pressure tracing with external and intra-aortic phonocardiograms. This confirms that the ejection sound originates at the aortic root and occurs at the apex of the first pressure rise in the aortic root.

TABLE VII

Group IV: Mobile Calcified Aortic Valves

Relationship of Hemodynamic and Phonocardiographic eVents to Valve Movement (all time intervals in msec.)

\begin{tabular}{|c|c|c|c|c|c|c|c|c|}
\hline Patient & & $\begin{array}{l}\text { Q aortic* } \\
\text { pressure } \\
\text { rise }\end{array}$ & $\begin{array}{l}\text { Q ejection } \\
\text { click }\end{array}$ & $\begin{array}{c}\mathbf{Q} \text { valve } \\
\text { open }\end{array}$ & $\begin{array}{l}\text { Q dicrotic* } \\
\text { notch }\end{array}$ & $\begin{array}{l}\text { Q second } \\
\text { heart } \\
\text { sound }\end{array}$ & $\begin{array}{l}\mathbf{Q} \text { valve } \dagger \\
\text { closed }\end{array}$ & $\begin{array}{c}\text { Systolic } \\
\text { gradient } \\
(\mathrm{mm} . \mathrm{Hg})\end{array}$ \\
\hline $\begin{array}{l}\text { Mixed stenosis } \\
\text { and } \\
\text { incompetence }\end{array}$ & $\left\{\begin{array}{l}\text { A.B. } \\
\text { C.H. } \\
\text { W.E. } \\
\text { A.R. }\end{array}\right.$ & $\begin{array}{l}70 \\
50 \\
85 \\
90\end{array}$ & $\frac{95}{-}$ & $\begin{array}{r}90 \\
85 \\
125 \\
140\end{array}$ & $\begin{array}{l}405 \\
385 \\
410 \\
470\end{array}$ & $\begin{array}{l}405 \\
390 \\
410 \\
470\end{array}$ & $\begin{array}{l}405 \\
385 \\
405 \\
475\end{array}$ & $\begin{array}{r}35 \\
40 \\
100 \\
40\end{array}$ \\
\hline Mean values & & 75 & - & 110 & 410 & 418 & 418 & 54 \\
\hline
\end{tabular}

* Pressure timings corrected for delay due to catheter transmission.

$\dagger$ All cine-angiogram timings subject to an error of $\pm 16.67 \mathrm{msec}$. 
TABLE VIII

Group V: Immobile Calcified Aortic Valves

Relationship of Hemodynamic and Phonocardiographic Events to valve movement (all time intervals in msec.)

\begin{tabular}{|c|c|c|c|c|c|c|c|c|}
\hline \multicolumn{2}{|l|}{ Patient } & $\begin{array}{l}\text { Q aortic* } \\
\text { pressure } \\
\text { rise }\end{array}$ & $\begin{array}{c}\mathbf{Q} \text { valve } \\
\text { open }\end{array}$ & $\begin{array}{l}\text { Q LV/ } \\
\text { aortic* } \\
\text { cross-over }\end{array}$ & $\begin{array}{l}\text { Q dicrotic* } \\
\text { notch }\end{array}$ & $\begin{array}{l}\text { Q second } \\
\text { heart } \\
\text { sound }\end{array}$ & $\begin{array}{l}\text { Q valve† } \\
\text { closed }\end{array}$ & $\begin{array}{c}\text { Systolic } \\
\text { gradient } \\
(\mathrm{mm} . \mathrm{Hg})\end{array}$ \\
\hline $\begin{array}{l}\text { Mixed stenosis } \\
\text { and } \\
\text { incompetence }\end{array}$ & $\left\{\begin{array}{l}\text { S.S. } \\
\text { R.C. } \\
\text { S.V. } \\
\text { R.B. } \\
\text { F.R. } \\
\text { M.L. } \\
\text { J.K. } \\
\text { D.B. } \\
\text { J.M. }\end{array}\right.$ & $\begin{array}{l}70 \\
90 \\
75 \\
75 \\
80 \\
85 \\
50 \\
80 \\
85\end{array}$ & $\begin{array}{r}105 \\
130 \\
110 \\
95 \\
135 \\
115 \\
115 \\
105 \\
115\end{array}$ & $\begin{array}{c}360 \\
415 \\
335 \\
360 \\
340 \\
380 \\
= \\
\overline{440}\end{array}$ & $\begin{array}{l}400 \\
460 \\
380 \\
385 \\
380 \\
405 \\
390 \\
355 \\
480\end{array}$ & $\begin{array}{c}400 \\
450 \\
375 \\
? \\
? \\
400 \\
? \\
? \\
?\end{array}$ & $\begin{array}{l}410 \\
460 \\
380 \\
395 \\
375 \\
405 \\
390 \\
355 \\
480\end{array}$ & $\begin{array}{r}87 \\
105 \\
30 \\
110 \\
80 \\
78 \\
90 \\
67 \\
55\end{array}$ \\
\hline Mean values & & 77 & 114 & 376 & 404 & 406 & 406 & 78 \\
\hline
\end{tabular}

* Pressure timings corrected for delay due to catheter transmission.

$\dagger$ All cine-angiogram timings subject to an error of $\pm 16.67 \mathrm{msec}$.

simultaneous pressure recordings, and these confirmed these findings and strongly supported the assumption that the clicks heard originated from the aortic valve (Fig. 8).

Measurements of Time Intervals. Tables IX-XIII show the measured phases of the cardiac cycle for each group; they also show the values of the factors taken into account in making comparisons between groups. It can be seen that the electrical-mechanical interval is prolonged over the normal values in the group with acquired aortic incompetence, and analysis showed that this prolongation was statistically significant $(p<0 \cdot 01)$. There was no significant difference between the

TABLE IX

Group I: Subdivisions of Cardiac Cycle

NoRmal SUBJECTS

(all time intervals in msec.; all pressures in $\mathrm{mm}$. $\mathrm{Hg}$ )

\begin{tabular}{c|c|c|c|c|c|c|c}
\hline Patient & $\begin{array}{c}\text { Age } \\
\text { (yr.) }\end{array}$ & $\begin{array}{c}\text { Electrical- } \\
\text { mechanical } \\
\text { interval* }\end{array}$ & $\begin{array}{c}\text { Isometric } \\
\text { contraction } \\
\text { time }\end{array}$ & $\begin{array}{c}\text { Ejection } \\
\text { timef }\end{array}$ & $\begin{array}{c}\text { Heart rate } \\
\text { (beats per } \\
\text { min.) }\end{array}$ & $\begin{array}{c}\text { Aortic } \\
\text { root } \\
\text { pressures }\end{array}$ & $\begin{array}{c}\text { LV end- } \\
\text { diastolic } \\
\text { pressures }\end{array}$ \\
\hline R.B. & 40 & 45 & 50 & 305 & 97 & $128 / 60$ & 16 \\
K.D. & 42 & 55 & 60 & 275 & 95 & $112 / 64$ & 11 \\
P.F. & 43 & 50 & 45 & 280 & 95 & $130 / 67$ & 10 \\
W.L. & 42 & 35 & 55 & 340 & 91 & $111 / 77$ & 5 \\
K.R. & 46 & 45 & 50 & 335 & 83 & $170 / 99$ & 10 \\
R.B. & 48 & 35 & 75 & 255 & 114 & $139 / 94$ & 9 \\
E.S. & 50 & 20 & 70 & 270 & 107 & $105 / 63$ & 3 \\
W.W. & 39 & 50 & 60 & 320 & 75 & $118 / 75$ & 5 \\
A.B. & 40 & 35 & 45 & 290 & 93 & $114 / 75$ & 170 \\
M.McL. & 51 & 50 & 55 & 360 & 76 & $170 / 73$ & 11 \\
R.W. & 38 & 30 & 80 & 260 & 113 & $112 / 81$ & 9 \\
P.L. & 35 & 40 & 50 & 320 & 64 & $132 / 62$ & 16 \\
\hline Mean values & 43 & 40 & 58 & 304 & 92 & $126 / 74$ & 10 \\
\hline
\end{tabular}

* O II-LV pressure rise (corrected for delay due to catheter transmission).

† LV pressure rise-aortic pressure rise.

$\ddagger$ Aortic pressure rise-dicrotic notch. 
TABLE $X$

Group II: Subdivisions of Cardiac Cycle

INCOMPETENT TRICUSPID AorTic VALVES

(all time intervals in $\mathrm{msec}$; all pressures in $\mathrm{mm}$. $\mathrm{Hg}$ )

\begin{tabular}{|c|c|c|c|c|c|c|c|c|}
\hline \multicolumn{2}{|c|}{ Patient } & $\begin{array}{l}\text { Age } \\
\text { (yr.) }\end{array}$ & $\begin{array}{l}\text { Electrical- } \\
\text { mechanical } \\
\text { interval* }^{*}\end{array}$ & $\begin{array}{l}\text { Isometric } \\
\text { contraction } \\
\text { time } \dagger\end{array}$ & $\begin{array}{c}\text { Ejection } \\
\text { time } \ddagger\end{array}$ & $\begin{array}{c}\text { Heart rate } \\
\text { (beats per } \\
\text { min.) }\end{array}$ & $\begin{array}{c}\text { Aortic } \\
\text { root } \\
\text { pressures }\end{array}$ & $\begin{array}{l}\text { LV end- } \\
\text { diastolic } \\
\text { pressures }\end{array}$ \\
\hline $\begin{array}{l}\text { Pure aortic } \\
\text { incompetence }\end{array}$ & $\begin{array}{l}\text { M.P. } \\
\text { B.M. } \\
\text { C.A. } \\
\text { T.H. } \\
\text { M.K. } \\
\text { D.D. } \\
\text { H.L. } \\
\text { M.B. } \\
\text { D.M. }\end{array}$ & $\begin{array}{l}30 \\
30 \\
38 \\
52 \\
42 \\
33 \\
56 \\
45 \\
35\end{array}$ & $\begin{array}{l}60 \\
35 \\
60 \\
40 \\
70 \\
65 \\
70 \\
40 \\
50\end{array}$ & $\begin{array}{l}30 \\
65 \\
25 \\
35 \\
35 \\
30 \\
25 \\
35 \\
40\end{array}$ & $\begin{array}{l}240 \\
270 \\
235 \\
250 \\
240 \\
285 \\
235 \\
240 \\
220\end{array}$ & $\begin{array}{r}94 \\
59 \\
85 \\
91 \\
89 \\
100 \\
84 \\
92 \\
90\end{array}$ & $\begin{array}{r}110 / 60 \\
86 / 47 \\
105 / 50 \\
117 / 43 \\
71 / 43 \\
108 / 70 \\
90 / 60 \\
120 / 70 \\
100 / 60\end{array}$ & $\begin{array}{r}8 \\
6 \\
19 \\
11 \\
10 \\
6 \\
10 \\
5 \\
4\end{array}$ \\
\hline Mean values & & 40 & 54 & 35 & 246 & 87 & $101 / 59$ & 9 \\
\hline
\end{tabular}

* Q II-LV pressure rise (corrected for delay in catheter transmission).

† LV pressure rise-aortic pressure rise.

$¥$ Aortic pressure rise-dicrotic notch.

TABLE XI

Group III: Subdivisions of Cardiac Cycle

Bicuspid Aortic Valves

(all time intervals in msec.; all pressures in $\mathrm{mm} . \mathrm{Hg}$ )

\begin{tabular}{|c|c|c|c|c|c|c|c|c|c|c|}
\hline Patier & & Age & Electrical- & Isometric & Corrected & Ejection & Corrected & Heart & Aortic & LV end- \\
\hline & & 15 & 60 & 30 & 75 & 335 & 290 & 75 & $88 / 57$ & 7 \\
\hline & D.M & 38 & 35 & 50 & 95 & 360 & 315 & 83 & $144 / 43$ & 19 \\
\hline & G.R. & 56 & 20 & 30 & 100 & 275 & 205 & 115 & $160 / 80$ & 15 \\
\hline & J.G. & 47 & 60 & 15 & 60 & 395 & 35 & 68 & & 2 \\
\hline Pure aortic & S.H. & 39 & 40 & 30 & 70 & 240 & 200 & 100 & $150 / 80$ & $\begin{array}{r}24 \\
0\end{array}$ \\
\hline incom- & S.C. & 34 & 45 & 35 & 65 & 270 & 240 & 77 & $150 / 74$ & 3 \\
\hline petence & R.A. & 17 & 35 & 30 & 85 & 355 & 300 & 70 & $158 / 70$ & 17 \\
\hline & W.S. & 18 & 45 & 25 & 60 & 320 & 285 & 88 & $142 / 75$ & 18 \\
\hline & J.B. & 15 & 40 & 30 & 75 & 360 & 315 & 70 & $118 / 40$ & 15 \\
\hline & B.B. & 23 & 40 & 40 & 60 & 280 & 260 & 85 & $110 / 70$ & 0 \\
\hline & M.C. & 17 & 50 & 20 & 60 & 240 & 200 & 104 & $120 / 80$ & 5 \\
\hline Mixed & A.R. & $\begin{array}{l}10 \\
22\end{array}$ & $\begin{array}{l}50 \\
55\end{array}$ & $\begin{array}{l}40 \\
35\end{array}$ & $\begin{array}{l}60 \\
65\end{array}$ & $\begin{array}{l}265 \\
320\end{array}$ & 245 & 100 & 100/71 & 8 \\
\hline stenosis & $\begin{array}{l}\text { M.P. } \\
\text { P.T. }\end{array}$ & 22 & 45 & 35 & 55 & 300 & 28 & $\begin{array}{l}94 \\
61\end{array}$ & $\begin{array}{l}97 / 64 \\
78 / 52\end{array}$ & $\begin{array}{l}9 \\
9\end{array}$ \\
\hline and & $A . F$ & 19 & 30 & 45 & 80 & 305 & 270 & 94 & $91 / 56$ & 6 \\
\hline incom- & J.N. & 43 & 40 & 40 & 60 & 280 & 260 & 110 & $\begin{array}{l}71 / 60 \\
106 / 60\end{array}$ & 6 \\
\hline petence & J.F. & 35 & 50 & 40 & 50 & 24 & 25 & 102 & $112 / 67$ & 7 \\
\hline & I.C. & 51 & 60 & 50 & 70 & 40 & 38 & 83 & $80 / 50$ & 6 \\
\hline & S.R. & 23 & 60 & 40 & 60 & 280 & 260 & 100 & $91 / 70$ & \\
\hline Pure & J.F. & 28 & 45 & 30 & 75 & 325 & 280 & 88 & $120 / 76$ & 15 \\
\hline aortic & N.H. & 37 & 30 & 25 & 40 & 300 & 270 & 90 & $116 / 60$ & 0 \\
\hline stenosis & R.F. & 31 & 50 & 30 & 70 & 300 & 26 & 100 & $94 / 71$ & 0 \\
\hline & W. & & 45 & & 80 & 280 & & 112 & $110 / 90$ & 4 \\
\hline Mean value & & 29 & 45 & 34 & 68 & 305 & 271 & 90 & $181 / 63$ & 9 \\
\hline
\end{tabular}

* Q II-LV pressure rise (corrected for delay due to catheter transmission).

† LV pressure rise-aortic pressure rise.

† LV pressure rise-ejection click.

\$ Aortic pressure rise-dicrotic notch.

** Ejection click-dicrotic notch. 
TABLE XII

Group IV: Subdivisions of CARDiac CyCle

Mobile Calcified Aortic Valves

(all time intervals in msec.; all pressures in $\mathrm{mm}$. $\mathrm{Hg}$ )

\begin{tabular}{|c|c|c|c|c|c|c|c|c|c|c|}
\hline \multicolumn{2}{|c|}{ Patients } & $\begin{array}{l}\text { Age } \\
\text { (yr.) }\end{array}$ & $\begin{array}{c}\text { Electrical- } \\
\text { mechanical } \\
\text { interval* }^{*}\end{array}$ & $\begin{array}{c}\text { Isometric } \\
\text { con- } \\
\text { traction } \\
\text { time } \dagger\end{array}$ & $\begin{array}{c}\text { Corrected } \\
\text { isometric } \\
\text { con- } \\
\text { traction } \\
\text { time } \neq\end{array}$ & $\begin{array}{c}\text { Ejection } \\
\text { time§ }\end{array}$ & $\begin{array}{l}\text { Corrected } \\
\text { ejection } \\
\text { time** }\end{array}$ & $\begin{array}{l}\text { Heart rate } \\
\text { (beats per } \\
\text { min.) }\end{array}$ & $\begin{array}{c}\text { Aortic } \\
\text { root } \\
\text { pressures }\end{array}$ & $\begin{array}{l}\text { LV end- } \\
\text { diastolic } \\
\text { pressure }\end{array}$ \\
\hline $\begin{array}{l}\text { Mixed } \\
\text { stenosis } \\
\text { and } \\
\text { incom- } \\
\text { petence }\end{array}$ & $\begin{array}{l}\text { A.B. } \\
\text { C.H. } \\
\text { W.E. } \\
\text { H.B. } \\
\text { J.Mc. }\end{array}$ & $\begin{array}{l}22 \\
44 \\
65 \\
57 \\
54\end{array}$ & $\begin{array}{l}50 \\
30 \\
55 \\
70 \\
40\end{array}$ & $\begin{array}{l}20 \\
20 \\
30 \\
25 \\
30\end{array}$ & $\begin{array}{l}55 \\
65 \\
70 \\
50 \\
40\end{array}$ & $\begin{array}{l}350 \\
335 \\
325 \\
295 \\
360\end{array}$ & $\begin{array}{l}315 \\
291 \\
285 \\
270 \\
350\end{array}$ & $\begin{array}{l}70 \\
83 \\
83 \\
65 \\
71\end{array}$ & $\begin{array}{r}104 / 42 \\
112 / 43 \\
92 / 50 \\
130 / 54 \\
69 / 42\end{array}$ & $\begin{array}{r}10 \\
10 \\
9 \\
9 \\
12\end{array}$ \\
\hline Mean valu & & 48 & 49 & 25 & 56 & 333 & 302 & 74 & $101 / 46$ & 10 \\
\hline
\end{tabular}

* Q II-LV pressure rise (corrected for delay due to catheter transmission).

† LV pressure rise-aortic pressure rise.

\# LV pressure rise-ejection click or peak of first pressure rise in aorta.

$\S$ Aortic pressure rise-dicrotic notch.

** Peak of first pressure rise-dicrotic notch.

normal and the other groups. This suggests that incompetence of the aortic valve per se prolongs the electrical-mechanical interval.

The isometric contraction time was considerably shorter in the groups with abnormal valves compared with the normal group. Statistical analysis showed that this shortening was highly significant $(p<0.001)$ for each group and that it was a function of the aortic valve rather than

TABLE XIII

Group V: Subdivisions of Cardiac Cycle

IMmobile CALCIFIEd Aortic Valves

(all time intervals in msec.; all pressures in $\mathrm{mm}$. $\mathrm{Hg}$ )

\begin{tabular}{|c|c|c|c|c|c|c|c|c|c|c|}
\hline \multicolumn{2}{|c|}{ Patients } & $\begin{array}{l}\text { Age } \\
\text { (yr.) }\end{array}$ & $\begin{array}{c}\text { Electrical- } \\
\text { mechanical } \\
\text { interval* }\end{array}$ & $\begin{array}{c}\text { Isometric } \\
\text { con- } \\
\text { traction } \\
\text { time† }\end{array}$ & $\begin{array}{c}\text { Corrected } \\
\text { isometric } \\
\text { con- } \\
\text { traction } \\
\text { time } \neq\end{array}$ & $\begin{array}{l}\text { Ejection } \\
\text { time§ }\end{array}$ & $\begin{array}{l}\text { Corrected } \\
\text { ejection } \\
\text { time** }\end{array}$ & $\begin{array}{c}\text { Heart rate } \\
\text { (beats per } \\
\text { min.) }\end{array}$ & $\begin{array}{c}\text { Aortic } \\
\text { root } \\
\text { pressures }\end{array}$ & $\begin{array}{l}\text { LV end- } \\
\text { diastolic } \\
\text { pressure }\end{array}$ \\
\hline $\begin{array}{l}\text { Mixed } \\
\text { stenosis } \\
\text { and } \\
\text { incom- } \\
\text { petence }\end{array}$ & $\begin{array}{l}\text { S.H. } \\
\text { R.C. } \\
\text { S.V. } \\
\text { R.B. } \\
\text { F.R. } \\
\text { M.L. } \\
\text { J.K. } \\
\text { D.B. } \\
\text { J.N. }\end{array}$ & $\begin{array}{l}50 \\
55 \\
49 \\
36 \\
50 \\
45 \\
30 \\
43 \\
48\end{array}$ & \begin{tabular}{|l|}
40 \\
50 \\
40 \\
50 \\
40 \\
40 \\
20 \\
50 \\
55
\end{tabular} & $\begin{array}{l}30 \\
35 \\
35 \\
25 \\
40 \\
45 \\
30 \\
30 \\
30\end{array}$ & $\begin{array}{l}70 \\
75 \\
65 \\
55 \\
90 \\
85 \\
85 \\
70 \\
70\end{array}$ & $\begin{array}{l}290 \\
325 \\
260 \\
300 \\
250 \\
295 \\
340 \\
275 \\
395\end{array}$ & $\begin{array}{l}250 \\
280 \\
230 \\
270 \\
210 \\
255 \\
285 \\
235 \\
355\end{array}$ & $\begin{array}{r}88 \\
88 \\
70 \\
92 \\
100 \\
94 \\
89 \\
75 \\
69\end{array}$ & $\begin{array}{r}92 / 52 \\
75 / 55 \\
100 / 48 \\
97 / 60 \\
95 / 63 \\
82 / 56 \\
82 / 45 \\
117 / 78 \\
79 / 35\end{array}$ & $\begin{array}{r}28 \\
28 \\
6 \\
32 \\
22 \\
34 \\
17 \\
9 \\
44\end{array}$ \\
\hline \multicolumn{2}{|c|}{ Mean values } & 45 & 42 & 33 & 75 & 304 & 264 & 85 & $91 / 56$ & 23 \\
\hline
\end{tabular}

* Q II-LV pressure rise (corrected for delay due to catheter transmission).

$\dagger$ LV pressure rise-aortic pressure rise.

IVV pressure rise-peak of first pressure rise in aorta.

$\$$ Aortic pressure rise-dicrotic notch.

** Peak of first pressure rise-dicrotic notch. 
differences in heart rate, aortic diastolic pressure, etc. However, the cine-angiographic timing showed that aortic valve opening was considerably later than the pressure rise in the aortic root. Since isometric contraction is defined as the interval between mitral valve closure and aortic valve opening (Wiggers, 1949), a second measurement (corrected isometric contraction) from the rise of pressure in the left ventricle to the ejection click or the peak of the first pressure rise in the aortic root was made in Groups III-V. It can be seen from the Tables that this interval is much longer than isometric contraction in the normal group. Statistical analysis showed that this prolongation was highly significant $(p<0.001)$ in Groups III and V, but not in Group IV $(p<0.8)$. This prolongation was related to the abnormality of the aortic valve rather than the other factors.

Since ejection time was measured from the first rise of aortic pressure to the dicrotic notch, a similar, but negative, correction had to be applied. The corrected ejection time was significantly reduced $(\mathrm{p}<0.01)$ in all but Group IV $(\mathrm{p}<0 \cdot 8)$.

\section{Discussion}

The events of the cardiac cycle and the associated movements of the heart valves were first described in detail by Wiggers (1949). He inferred that the aortic valve opened promptly when the pressure in the left ventricle rose above that in the aortic root, and closed just as promptly when left ventricular pressure fell below that in the aortic root. This event is marked by the dicrotic notch on the aortic root pressure tracing. It is generally accepted that aortic valve closure contributes to the second heart sound (McKusick, 1958; Essex, Smith, and Baldes, 1953), and the dicrotic notch on the carotid arteriogram is commonly used to identify this component in phonocardiograms. The contribution of aortic valve opening to the first heart sound, if any, is still sub judice (Luisada and Shah, 1963).

This concept of valve action has been uncritically extended to valvular disease of the heart, and it is assumed that abnormal valves necessarily follow the same pattern. As a result, there has been much confusion regarding the origin of the early aortic systolic click. This sound is associated with a variety of conditions affecting the left side of the heart, particularly congenital aortic stenosis, congenital truncus arteriosus communis, and systemic hypertension (McKusick, 1958; Minhas and Gasul, 1959). A similar sound is associated with similar conditions affecting the right side of the heart, but the two can easily be distinguished on clinical grounds (Leatham and Vogelpoel, 1954). The physical characteristics of the early systolic sound, the shortness of its duration, and its general similarity to the opening snap of the stenotic mitral valve, led to the suggestion that it was an opening snap of the semilunar valves (Arrigola and Taquina, 1941; Wolferth and Margolies, 1945), and possibly an accentuation of a normal contribution to the first heart sound (Minhas and Gasul, 1959). Leatham and Vogelpoel (1954) made the observation that this sound was invariably preceded by a rise in pressure in the carotid artery as recorded by the carotid arteriogram. From this they argued that the sound could not be associated with opening of the semilunar valves, but rather with ejection of blood into the great vessels. They noted that in many of these cases the great vessels were dilated, and suggested that the sound was generated in the vessel walls by ventricular ejection and made clearly audible by the fact that the dilated vessels were nearer the surface of the chest. Hence the name "ejection click" which they coined. Minhas and Gasul (1959) reported 146 patients with early systolic clicks associated with a wide variety of conditions. They felt strongly that the sounds heard in pulmonary and aortic stenosis were semilunar opening snaps, and in support of this they pointed out that the sound always preceded the systolic murmur in these conditions. Furthermore, they maintained that the carotid arteriogram did not invariably show a rise of pressure before the systolic sound. One of their published tracings showed a pressure rise to an early peak on the central aortic tracing before the click; they ascribed this pressure rise to a reflection of the pressure events of isometric contraction in the left ventricle across the aortic valve, that is, as analogous to Frank's wave which is commonly seen on the normal aortic root pressure tracing (Wiggers, 1949). In 9 cases of truncus arteriosus with no obvious abnormality of the aortic valve the average QII- 
systolic click interval was 10 msec. more than in the group with valve stenosis. Hence, they felt justified in suggesting that the click in these cases was not an opening snap, but a true ejection sound related to dilatation of the aorta. Hancock (1961) maintained that the systolic click in aortic stenosis always coincided with the initial pressure rise on the carotid arteriogram. He published a tracing similar to that of Minhas and Gasul, and offered the same explanation. Other workers have published similar observations supporting the opening snap theory in pulmonary stenosis (McKusick et al., 1956; Davidsen, 1958). Hultgren (1956) produced evidence that systolic clicks originated at the pulmonary annulus and not from the main vessel.

Table II confirms that the normal valve opens and closes at the appropriate points in the cardiac cycle, and in the group with tricuspid incompetent aortic valves (Table III) the same relationships were observed. However, from Tables IV-VIII it can be seen that when there is valvular obstruction to the left ventricular outflow tract, there is a pressure rise in the aortic root which precedes valve opening. In those patients in whom an early systolic click was present, it coincided with the peak of this initial rise: 9 of them did not have a systolic pressure difference, that is, there was no valve stenosis; hence it might be thought that they did not present an obstruction to left ventricular outflow. However, all had bicuspid aortic valves, and it is generally accepted that a bicuspid valve cannot open as widely as a tricuspid valve (McKusick, 1958; Edwards, 1961, 1962; Bentivoglio et al., 1960). Hence it must present some obstruction to outflow, even in the absence of a pressure difference.

Those patients with early systolic clicks all had bicuspid valves, and most showed a characteristic upward doming of the valve into the aortic root which coincided with the click. No systolic sounds were recorded in those patients in whom the aortic valve was calcified and neither was this characteristic dome seen. This suggests that the bicuspid aortic valve requires a pressure difference to open it sufficiently for ejection to take place. If the valve is mobile and pliable, then it will be everted upwards into the aortic root, and the checking of this upward movement produces a clicking sound. The calcified valve is too stiff and thickened to be everted, and though a pressure difference is still required to open it, no sound is generated. Synthetic valve leaflets are clearly stiffer and less pliable than the normal valve, and it is not surprising to find that they also require a pressure difference to open them, and generate an early systolic sound as well.

Congenital bicuspid aortic valves are not usually associated with a sytolic ejection sound (Tranchesi et al., 1957). However, Bentivoglio et al. (1960) reported systolic clicks in 3 out of 6 proven cases. Bicuspid aortic valves are associated with coarctation of the aorta, estimates ranging from 42 per cent (Reifenstein, Levine and Gross, 1947) to 89 per cent (Edwards, 1961) of cases. McKusick (1958) observed that ejection clicks were commonly associated with coarctation, but felt that this must be a consequence of hypertension and dilatation of the ascending aorta. Braimbridge (1963) did not commonly observe dilatation of the ascending aorta in his series of 119 cases of coarctation, but he recorded ejection clicks in 66 per cent. The incidence of congenital bicuspid aortic valves in necropsy specimens is estimated as 1.5 per cent and the incidence of acquired bicuspid aortic valves as 0.5 per cent (Koletsky, 1941a,b). Furthermore, bicuspid aortic valve is said to be the commonest single cardiac anomaly (Koletsky, 1941a). On the other hand, dilatation of the aorta is common, but is not invariably associated with an ejection click, and it seems reasonable to suggest that when a click is present, it is more likely to be an opening snap of a bicuspid valve, as suggested by the data presented here, than a consequence of dilatation of the great vessels. It may be that it is accentuated and more obvious to the auscultator under conditions that demand a large stroke output, such as aortic valve incompetence, and hence produce violent movement of the valve. There is some evidence that this is so.

One inconsistency in the data presented is the absence of the cine-angiographic "dome" in 6 of the patients with ejection clicks. This appearance is clearly a function of the size of the systolic orifice, and the position of the patient during filming. In one patient (P.T.) with an obvious "dome" in the left anterior oblique position, there was no such appearance in the right anterior oblique position. 
TABLE XIV

SUB-DIVISIONS OF THE CARDIAC CYCLE

(all time intervals in msec.)

\begin{tabular}{lll|c|c|c|c|c|c}
\hline Author & & & $\begin{array}{c}\text { No. of } \\
\text { patients }\end{array}$ & $\begin{array}{c}\text { Electrical- } \\
\text { mechanical } \\
\text { interval }\end{array}$ & $\begin{array}{c}\text { Isometric } \\
\text { con- } \\
\text { traction } \\
\text { time }\end{array}$ & $\begin{array}{c}\text { SI } \\
\text { ejection } \\
\text { click } \\
\text { time }\end{array}$ & $\begin{array}{c}\text { Ejection } \\
\text { time }\end{array}$ & $\begin{array}{c}\text { Q ejection } \\
\text { click } \\
\text { time }\end{array}$ \\
\hline & & & & & & & & \\
\hline
\end{tabular}

* Direct measurements.

It is well known that the second heart sound may be normal or accentuated in congenital aortic stenosis (McKusick, 1958; Campbell and Baylis, 1956; Reinhold, Rudhe, and Bonham-Carter, 1955) and congenital bicuspid aortic valve (Bentivoglio et al., 1960), and this is consistent with the sudden return of the valve "dome" to its resting position. However, the observed delay in the dicrotic notch and aortic component of the second heart sound in these patients with calcific stenosis is not so easily understandable. It is possible that the heavily calcified valve is so stiff and difficult to move that it lags behind the pressure changes at all phases of the cardiac cycle, but this observation needs to be fully confirmed.

From the above it is clear that precise measurement of the phases of the cardiac cycle in aortic valve disease cannot be made by the methods used for normal hearts since valve measurement is not related to the pressure events in the same way. Table XIV lists previous estimates of these phase intervals taken from the published reports. There is a wide variation in the values obtained both for normal and abnormal hearts, and this is hardly surprising when it is considered that most of them were obtained by indirect methods, e.g. subtraction of a standard delay figure from the carotid arteriogram, which are of doubtful validity (Boone, Ellinger, and Gillick, 1949). Furthermore, no corrections have been made for differences in heart rate, cardiac index etc., all of which affect these intervals considerably. Hence no two sets of measurements can be closely compared.

Nevertheless, it is clear that the electrical-mechanical interval is relatively constant, with the exception of aortic incompetence. Lengthening of this interval in patients with aortic incompetence is confirmed by the data presented here, and though the figure obtained is much smaller than in the previous report of Sutton, Hohf, and Gibney (1962), the variation from the normal is clearly significant. Lengthening of the electrical-mechanical interval was not seen in those patients in Group III with aortic incompetence; the explanation for this probably lies in the fact that the degree of 
incompetence was trivial in all but two. The significance of this delay in response of the myocardium is not known, but it is clearly not a function of ventricular hypertrophy. A similar phenomenon is seen in patients after myocardial infarction and with hypertension (Gibney, Sutton, and McEwen, 1961), and this suggests that it reflects impaired myocardial contractility.

The measurements of isometric contraction time made in the group of normals in this series compare well with previous direct measurements (Table XIV). Group II shows a significant reduction in isometric contraction time, confirming previous observations (Sutton et al., 1962; Gordon, Kirschner, and Moscovitz, 1961). Reduction of the isometric contraction time is thought to be due to low aortic diastolic pressure, but this method of analysis shows that the reduction is significant even when this variable is allowed for. This suggests that the incompetence per se produces changes that shorten isometric contraction while lengthening the electrical-mechanical interval. It is possible that the increased residual volume of the ventricle is the direct cause. Isometric contraction in the other groups, if measured to the first pressure rise in the aorta, is much reduced; but when the true measurement is made, this interval is clearly greatly increased, and this increase is a function of the valve abnormality and not of the incidental hæmodynamic differences in heart rate, etc. This might be expected if a pressure gradient had to be established before the valve opened. The results obtained with Group IV are not consistent with this, but the number of cases is so small that statistical analysis is not valid.

When the ejection time is measured from the first pressure rise to the dicrotic notch, it seems to be prolonged in Groups III-V. However, the true measurement of ejection time is significantly shorter than in the normal group, and again this is a function of the valve abnormality and might be predicted from the observed differences in function from the normal.

\section{SUMMARY}

Aortic valve movements recorded by cine-angiography were correlated with hæmodynamic and phonocardiographic events of the cardiac cycle in normal patients and in patients with aortic valve disease. Valve movements were found to follow the classical sequence of events whenever the valve was tricuspid. Bicuspid non-calcified valves were found to open later than might be expected, and their opening coincided with an ejection click. Calcified valves also opened later, but there was usually no ejection click. In heavily calcified valves, closing occurred later than might be expected. The subdivisions of the cardiac cycle are reconsidered in the light of these findings. They are compared with the group of normal patients by means of a statistical technique which allows the true effects of valve abnormality to be observed.

My thanks are due to Dr. Richard S. Ross, and Dr. Raymond Daley, for permission to use their patients in this study, and to Dr. E. A. Murphy, for help with the statistical analysis.

\section{REFERENCES}

Arrigola, F. C., and Taquina, A. C. (1941). Chasquido de apertura de las Sigmoideos Pulmonares. Rev. argent. Cardiol., 8, 43.

Bentivoglio, L. G., Sagarminaga, J., Uricchio, J., and Goldberg, H. (1960). Congenital bicuspid aortic valves: a clinical and hæmodynamic study. Brit. Heart J., 22, 321.

Boone, B. R., Ellinger, G. F., and Gillick, F. G. (1949). The electrokymography of the heart and great vessels. Ann. intern. Med., 31, 1030.

Braimbridge, M. V. (1963). Surgery of the descending thoracic aorta. Ann. roy. Coll. Surg. Engl., 33, 344.

Braunwald, E., Fishman, A. P., and Cournand, A. (1956). Time relationship of dynamic events in the cardiac chambers, pulmonary artery and aorta in man. Circulat. Res., 4, 100.

—, Moscovitz, H. L., Amram, S. S., Lasser, R. P., Sapin, S. O., Himmelstein, A., Ravitch, M. M., and Gordon, A. J. (1955). Timing of electrical and mechanical events of the left side of the human heart. J. appl. Physiol., 8, 309.

Campbeli, M., and Baylis, J. H. (1956). The course and prognosis of coarctation of the aorta. Brit. Heart J., 18, 475.

Coghlan, C., Prieto, G., and Harrison, T. R. (1961). Movement of the heart during the period between the onset of ventricular excitation and the start of left ventricular ejection. Amer. Heart J., 62, 65. 
Davidsen, H. G. (1958). Pulmonary hypertension and incompetence with holodiastolic murmur in atrial septal defect. Acta med. scand., 160, 177.

Edwards, J. E. (1961). The congenital bicuspid aortic valve. Circulation, 23, 485. (1962). On the etiology of calcific stenosis. Circulation, 26, 817.

Essex, H. E., Smith, H. L., and Baldes, E. J. (1953). Origin of the heart sounds (Abstract). Fed. Proc., $12,40$.

Gibney, J. P., Sutton, G. C., and McEwen, E. G. (1961). The intervals of the cardiac cycle in several forms of heart disease other than mitral stenosis. Amer. J. med. Sci., 241, 503.

Gordon, A. J., Kirschner, P. A., and Moscovitz, H. L. (1961). Hemodynamics of Aortic and Mitral Valve Disease. Grune and Stratton, New York.

Hancock, E. W. (1961). Differentiation of valvar, sub-valvar, and supravalvar aortic stenosis. Guy's Hosp. Rep., 110, 1 .

- and Fleming, P. R. (1960). Aortic stenosis. Quart. J. Med., 29, 209.

Hultgren, H. N. (1956). Origin of the early systolic click of the pulmonary artery. Stanf. med. Bull., $14,183$.

Koletsky, S. (1941a). Congenital bicuspid aortic valves. Arch. intern. Med., 67, 129. (1941b). Acquired bicuspid aortic valves. Arch. intern. Med., 67, 157.

Luisada, A. A., and Shah, P. M. (1963). Controversial and changing aspects of auscultation. Amer. J. Cardiol., $11,774$.

Leatham, A., and Vogelpoel, L. (1954). The early systolic sound in dilatation of the pulmonary artery. Brit. Heart J., 16, 21.

McKusick, V. A. (1958). Cardiovascular Sound in Health and Disease. Williams and Wilkins, Baltimore.

-, Massengale, O. N., Jr., Wigod, M., and Webb, G. N. (1956). Spectral phonocardiographic studies in congenital heart disease. Brit. Heart J., 18, 403.

Mannheimer, E. (1940). Calibrated phonocardiography and electrocardiography. A clinical-statistical study of normal children and children with congenital heart disease. Acta paadiat. (Uppsala), 28, suppl. 2.

Minhas, K., and Gasul, B. M. (1959). Systolic clicks: A clinical, phonocardiographic and hemodynamic evaluation. Amer. Heart J., 57, 49.

Puchner, T. C., Hyuston, J. H., and Hellmuth, G. A. (1960). Heart sounds and murmurs in arterial hypertension. Amer. J. Cardiol., 6, 630.

Reifenstein, G. H., Levine, S. A., and Gross, R. E. (1947). Coarctation of the aorta. Amer. Heart J., 33, 146.

Reinhold, J., and Rudhe, U. (1957). Relation of the first and second heart sounds to events in the cardiac cycle. Brit. Heart J., 19, 473.

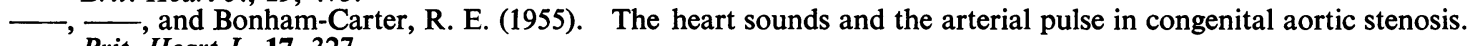
Brit. Heart J., 17, 327.

Seldinger, S. I. (1953). Catheter replacement of the needle in percutaneous arteriography. Acta radiol. (Stockh.), $39,368$.

Strober, M., Martirez, F., and Kelly, J. J. (1957). Factors influencing the time of onset of the first heart sound in normal subjects. Amer. Heart J., 54, 684.

Sutton, G. C., Hohf, R. P., and Gibney, J. P. (1962). Alterations in systolic components of the cardiac cycle in aortic and pulmonic valve insufficiency in human beings and experimental animals. Amer. J. med. Sci., $243,323$.

Tranchesi, J., Carral, R., Amorim, I. de, and Peñaloza, D. (1957). The clinical diagnosis of bicuspid aortic valve. Amer. Heart J., 47, 664.

Wiggers, C. J. (1949). Physiology in Health and Disease, 5th ed. Kimpton, London.

Wolferth, C. C., and Margolies, A. (1945). Heart sounds. In Diagnosis and Treatment of Cardiovascular Disease, ed. W. D. Stroud, 3rd ed., pp. 545-592. Davis, Philadelphia. 